JAZYKOVEDNÝ ČASOPIS, 2016, roč. 67, č. 1

\title{
RECENZIE A SPRÁVY
}

JEZIČNA KULTURA. PROGRAM I NASLIJEĐE PRAŠKE ŠKOLE. Uredio, preveo i uvod napisao Petar VUKOVIĆ. Zagreb: Srednja Europa 2015. 342 s. ISBN 9789537963248

V mnohých krajinách (napr. aj v dnešnom Japonsku) sa Pražskej lingvistickej škole dostáva aj dnes mimoriadnej pozornosti a uznania. Obdiv k dedičstvu Pražskej lingvistickej školy vyjadruje aj najnovšia jazykovokultúrna antológia „pražských“ textov, ktorá vyšla v r. 2015 pod názvom Jazyková kultúra. Program a dedičstvo Pražskej školy. Ide o zaujímavú antológiu, ktorú usporiadal, úvodom vybavil a jednotlivé texty preložil Petar Vuković, mimoriadny profesor slavistiky na Filozofickej fakulte Univerzity v Záhrebe, znalec (odkazu) Pražskej školy.

Jazykovokultúrny program Pražskej školy bol sformulovaný, ako je dostatočne známe, začiatkom 30. rokov 20. storočia ako súbor univerzálnych zásad na kultivovanie spisovného jazyka a jeho potrieb a práve vd’aka nim táto oblast' aplikovanej jazykovedy nadobudla modernú - v základe štrukturalistickú a funkčnú - bázu. Uvedený program sa vzápätí stal základom kultivovania spisovného jazyka v Čechách, ale v priebehu d’alších rokov si ich osvojila aj istá čast' slovenskej jazykovednej obce a od 50. rokov ju prijala aj medzinárodná spoločnost'. Doplňme, že napr. L. N. Zasorinová v Úvode do štruktúrnej lingvistiky (1974) považuje Prahu 30. - 40. rokov za ohnisko svetovej lingvistiky. Do Chorvátska učenie tejto školy preniesol podla editora predovšetkým Ljudevit Jonke, pričom jazyková situácia a rozvoj jazykovej kultúry v tejto balkánskej krajine má oproti Prahe svoje špecifiká. Ale nijaká koncepcia sa neprenáša nikam inam celkom bez zmien. Každá krajina a jazyková situácia má svoje špecifiká a tie mala a má, ako v úvodnej kapitole so znalost'ou veci vysvetl'uje editor, aj sama česká jazyková situácia. A povedané sa týka, pravdaže, aj slovenskej jazykovej situácie vo vzt’ahu k Pražskému lingvistickému krúžku.

Uvedená publikácia obsahuje preklad 20 českých a slovenských prác o jazykovej kultúre. Editor pritom vymedzuje hranice Pražskej školy dost' široko. Vo svojej antológii odtláča nielen všeobecne známe a uznávané klasické práce tejto školy, ale aj články „predchodcov“ alebo inšpirátorov Pražského lingvistického krúžku, ako aj články povojnových českých a slovenských lingvistov, ktorí tento program jazykovej kultúry d’alej rozvíjali. No nájdeme tu aj celkom súčasné práce, ktoré klasický štrukturalizmus Pražskej školy vnímajú kriticky, resp. ktoré ponúkajú inú, dalo by sa povedat' postštrukturalistickú, alternatívu jazykovej kultúry. Treba uznat', že väčšina prác, ktoré sa v antológii v chorvátskom preklade odtláčajú, sa v odbornej literatúre hodnotia ako prelomové. Napriek tomu však v istých prípadoch boli pri výbere zrejme rozhodujúce editorove subjektívne preferencie, ktoré spomína v úvodnej kapitole.

Ktoré texty teda vybral editor do kompendia? Sú to články „predchodcov“ Pražského lingvistického krúžku Jiř́ho Hallera a Václava Ertla: Z Jiř́iho Hallera sa sem dostala stat’ Problém jazykové správnosti II (1931), z Václava Ertla zasa Dobrý autor (1927) a okrem toho aj článok $O$ germanismech (1928). Potom prichádzajú preklady dobre známych štúdií z po- 
vestného zborníka Spisovná čeština a jazyková kultura (1932), z ktorého sa preberajú štúdie Viléma Mathesiusa $O$ požadavku stability ve spisovném jazyce, Bohuslava Havránka Úkoly spisovného jazyka a jeho kultura, Romana Jakobsona $O$ dnešním brusičství českém a Jana Mukařovského Jazyk spisovný a jazyk básnický. Z uvedeného súboru sa vynecháva teda jedine článok Miloša Weingarta Zvuková kultura českého jazyka.

Nasleduje článok Eugena Paulinyho Nárečie a spisovný jazyk z brožúry Dve kapitoly o spisovnom jazyku a náreči (1946), d’alej článok Miloša Dokulila Kotázce normy spisovného jazyka a její kodifikace zo Slova a slovesnosti (1952), štúdia Petra Sgalla Obecná čeština (vyšla pôvodne po rusky vo Voprosach jazykoznanija, 1962). Ďalej nasledujú dva články Jozefa Ružičku Problém jazykovej kultúry a Tézy o slovenskom jazyků (oba pochádzajú zo zborníka Problémy jazykovej kultúry, ktorý redigoval sám J. Ružička, 1967). Za nimi nasleduje článok Františka Daneša Dialektické tendence ve vývoji spisovných jazyků (přispěvek sociolingvistický), ktorý pôvodne vyšiel v Čs. prednáškach pre VI. medzinárodný zjazd slavistov v Prahe (1968). Ďalej je tu text Aloisa Jedličku Vývojová dynamika současné spisovné češtiny (z časopisu Naše řeč, 1968), ale je tu aj text Jána Horeckého K teórii spisovného jazyka (Jazykovedný časopis, 1981), d’alej úryvok od Zdeňka Starého s názvom Ve jménu funkce, ktorý pochádza z jeho knihy Ve jménu funkce a intervence (1995). A napokon tu nájdeme text Václava Cvrčka Koncept minimální intervence (z časopisu Slovo a slovesnost, 2008), ako aj Jiř́ho Neustupného Sociolingvistické aspekty modernizácie spoločnosti (vyšlo v angličtine 2006) a Jiřího Nekvapila Integratívny potenciál teórie jazykového manažmentu (vyšlo v angličtine, 2009).

P. Vuković vo svojom komentári pripomína v súvislosti s Pražskou lingvistickou školou vyjadrenie Otta Jespersena (1925, s. 87), že „language is an organism which develops best in a state of complete friedom, so that all dogmatizing or meddling with language is evil“", ktorý by sme do slovenčiny mohli preložit' napríklad takto: Jazyk je organizmus, ktorému sa najlepšie darí v podmienkach úplnej slobody, a každý druh dogmatizácie a zasahovania do jazyka je zlý.“ Spomína sa tu aj Robert A. Hall (1950), podl’a P. Vukovića ,jeden z najdôležitejších predstavitel'ov amerického štrukturalizmu“, ktorý svoju knihu priamo aj nazval Nechajte svoj jazyk na pokoji! Pripomeňme k tomu, že učenie Pražskej lingvistickej školy sa s týmto heslom celkom nekryje, ako to potvrdil aj František Daneš v článku Nenechávejte svi̊j jazyk na pokoji! (Vesmír, 2000). Zároveň však malo k nemu vel’mi blízko.

Editor spomína špecifiku českej jazykovej situácie, na ktorú narazila česká kultúra v 20. rokoch 20. storočia. Moderný český spisovný jazyk sa totiž utváral začiatkom 19. storočia oživením jazykovej normy zo 16. storočia, a to najmä v oblasti morfológie. V tom čase bola rozšírená predstava, že v 17. storočí sa začal proces jazykovej regresie a masívneho prívalu germanizmov a 16. storočie sa začalo vnímat’ ako „zlatý vek“ českého jazyka. V českých intelektuálnych kruhoch sa rozšírila predstava o nevyhnutnosti zásadnej intervencie do jazyka a do jazykovej praxe, čomu zodpovedalo posilnenie puristického prístupu k jazyku. Na druhej strane český jazyk sa už v 20. rokoch 20. storočia podl'a editora postupne menil na polyfunkčný a prestížny komunikačný prostriedok. Po osamostatnení Československa už český jazyk nebol ohrozený ako kedysi dominantnou nemčinou a v takých podmienkach tradičná puristická starostlivost' strácala svoju dôveryhodnost', najmä ak predstavitelia Pražskej lingvistickej školy ponúkli za n̆u plnohodnotnú alternatívu. To na rozdiel od jazykovej situácie na Slovensku, kde na začiatku 30. rokov puristický prístup kulminoval. 
V odbornej literatúre sa objavuje aj názor, že tradícia českého jazykového purizmu siaha až do začiatku 15. storočia, do čias, ked’ Ján Hus kritizoval okolnost', že Pražania hovoria „napoly česky, napoly nemecky“. Jazykový purizmus však neskôr bujnel nielen v Čechách, ale aj v iných krajinách stredovýchodnej a severnej Európy. Bol to ohlas na nemecký protifrancúzsky purizmus zo začiatku 19. storočia a reakcií naň. V podmienkach nemecko-francúzskych vojen začali nemeckí ,jazykoví aktivisti“ vyzývat' na vyrad'ovanie a likvidáciu galicizmov a ich zámenu za domáce výrazy. Tento xenofóbny jazykový purizmus sa postupne, ako ukazuje aj editor, rozšíril na európsky sever a východ. K nemu sa pridružili severogermánske národy a Fíni, ale aj Česi, Slováci, Mad’ari, Slovinci a Chorváti v rôznom tempe a s rôznou intenzitou s tým, že v týchto jazykových situáciách a jazykoch boli uvedené puristické hnutia orientované na boj proti germanizmom, potom postupne $\mathrm{v}$ slovenskej situácii najmä proti bohemizmom. Známe je, že v Čechách v 2. polovici 19. storočia sa objavilo vel'ké množstvo puristických príručiek, najznámejšie z nich boli tzv. brusy českého jazyka $(1877,1881,1894)$, ktoré vydávala Matica česká. Pripomeňme, že autorom jedného z nich (1887) bol aj náš Martin Hattala. Ale zápal pre čistenie jazyka neochaboval v Čechách ani na začiatku 20. storočia. Puristické články vychádzali v uvedenom čase i v serióznom jazykovednom časopise Naše řeč (vychádzajúcom od r. 1916), a to najmä od čias, ked’ sa jeho šéfredaktorom stal Jiří Haller (od r. 1929). Ide o najznámejšieho „moderného českého jazykového puristu“, ale i jedného z posledných puristov v Čechách. Práve jeho ostrá kritika súdobého jazyka a kritika tejto kritiky zo strany avantgardných českých autorov však podnietili jednu z najväčších polemík príslušnej českej kultúrnej obce, pričom podl'a editora Hallerove formulácie boli priamym podnetom a zámienkou na formulovanie programu jazykovej kultúry Pražskej školy.

Čo bolo jadrom Hallerovho prístupu k jazyku, odhal'ujú dva články Problém jazykové správnosti I a Problém jazykové správnosti II, z ktorých druhý otvára túto publikáciu. Ako vidiet', Haller bol voči tradičnému českému purizmu pomerne kritický, odmietal najmä jeho subjektivizmus pri hodnotení jazykových javov. Sám však prejavoval - na rozdiel od svojich predchodcov - omnoho viac pochopenia pre historizmus v jazyku, čo P. Vuković oprávnene vysvetl'uje ako vplyv mladogramatickej tradície. Aj Haller pritom občas odkazoval na isté štrukturalistické a funkčné postoje súdobých lingvistických prác. Nad’alej však zastával názor, že češtinu ohrozuje nemčina a že puristický prístup má svoj zmysel, iba je v ňom nevyhnutné posilnit' objektivitu a schopnost' argumentovat'. Na rozdiel od iných puristov 19. storočia pre Hallera nebolo dôležité logické a estetické kritérium.

Z komentára sa d’alej dozvedáme, že k tradičnému českému purizmu bol svojím spôsobom kritický aj d’alší autor Václav Ertl, o ktorom sa dá povedat', že na rozdiel od Hallera hl'adal inú alternatívu. Potvrdzujú to aj dva Ertlove články, ktoré sa odtláčajú v publikácii. Podobne ako Jiř́i Haller aj on sa pokúšal o objektívnejší základ, išiel však d’alej a tento základ staval výlučne na súčasnej jazykovospisovnej praxi. Urobil to najmä v článku Dobrý autor. Dobrí autori sú podl'a neho tí významní spisovatelia, ktorí majú široký okruh čitatel'ov, vd’aka čomu ich jazyk má najväčší vplyv na jazykové vedomie hovoriacich, ale za správne nemožno považovat' všetky javy, ktoré sa u nich vyskytujú, ale len tie, ktoré zodpovedajú väčšinovému použitiu. V článku $O$ germanismech Ertl už celkom kriticky reaguje na tradíciu českého jazykového purizmu. Boj proti germanizmom mal podl'a neho dôležitú spoločenskú úlohu, no po dosiahnutí emancipácie už nie je naň dôvod. Germanizmy sú zát’ǎou pre jazyk, ale v prípade, že sa štruktúrne prispôsobili domácemu jazyku a integrovali sa doň a bežne sa používajú, boj 
proti nim stráca akýkol'vek zmysel. Vinou svojej predčasnej smrti sa už nemohol zúčastnit’ na diskusiách Pražskej školy, no svojimi článkami podporil jej program.

Program jazykovej kultúry predstavitelia Pražskej lingvistickej školy formulovali predovšetkým v zborníku Spisovná čeština a jazyková kultura (1932), pričom isté prvky obsahujú už Tézy predstavené na 1. slavistickom kongrese v Prahe (Théses, 1929). V antológii sa oprávnene odkazuje na názory škandinávskych lingvistov Adolfa Noreena a Otta Jespersena, ktorých dobre poznal anglista Vilém Mathesius. Dôležitý bol aj vplyv Moskovského lingvistického krúžku, ktorý do Čiech prinášali predovšetkým Roman Jakobson a Nikolaj Trubeckoj. Nie je prekvapujúce, že v antológii P. Vukovića našiel svoje miesto predovšetkým prvý z nich.

Akokol'vek by sme mohli uvažovat' nad konkrétnym výberom konkrétnych autorov a konkrétnych textov Petara Vukovića do antológie (týka sa to aj zastúpenia slovenských autorov), je zrejmé, že už len „prenos“ týchto textov predstavuje nielen významnú „správu“ o dejinách slovanských spisovných jazykov adresovanú južno-slovanským oblastiam, ale je to aj dôležitý podnet do súčasného chorvátskeho jazykovopolitického a jazykovokultúrneho diskurzu, ktorému sa takáto vzpruha celkom zišla. Propagujú sa tu však zároveň aj texty slovenských autorov, a teda aj slovenská jazykoveda, hoci by sme možno vybrali pri niektorých z nich (E. Pauliny, J. Horecký) iné ich príspevky.

Slavomir Ondrejovič

Jazykovedný ústav L. Štúra SAV, Bratislava 